\title{
VARIABILITY OF SOIL FERTILITY PROPERTIES IN AREAS PLANTED TO SUGARCANE IN THE STATE OF GOIAS, BRAZIL $^{(1)}$
}

\author{
José Avelino Cardoso( ${ }^{(2)}$, Marilusa Pinto Coelho Lacerda ${ }^{(3)}$, Thomaz Adolpho Rein ${ }^{(4)}$, João \\ de Deus Gomes dos Santos Junior ${ }^{(4)}$ \& Cícero Célio de Figueiredo ${ }^{(5)}$
}

\begin{abstract}
SUMMARY
Soil sampling should provide an accurate representation of a given area so that recommendations for amendments of soil acidity, fertilization and soil conservation may be drafted to increase yield and improve the use of inputs. The aim of this study was to evaluate the variability of soil fertility properties of Oxisols in areas planted to sugarcane in the State of Goias, Brazil. Two areas of approximately $8,100 \mathrm{~m}^{2}$ each were selected, representing two fields of the Goiasa sugarcane mill in Goiatuba. The sugarcane crop had a row spacing of $1.5 \mathrm{~m}$ and subsamples were taken from 49 points in the row and 49 between the row with a Dutch auger at depths of 0.0-0.2 and 0.2-0.4 m, for a total of 196 subsamples for each area. The samples were individually subjected to chemical analyses of soil fertility $\left(\mathrm{pH}\right.$ in $\mathrm{CaCl}_{2}$, potential acidity, organic matter, $\mathrm{P}, \mathrm{K}, \mathrm{Ca}$ and $\mathrm{Mg}$ ) and particle size analysis. The number of subsamples required to compose a sample within the acceptable ranges of error of $5,10,20$ and $40 \%$ of each property were computed from the coefficients of variation and the Student $t$-value for $95 \%$ confidence. The soil properties under analysis exhibited different variabilities: high ( $\mathrm{P}$ and $\mathrm{K}$ ), medium (potential acidity, $\mathrm{Ca}$ and $\mathrm{Mg}$ ) and low ( $\mathrm{pH}$, organic matter and clay content). Most of the properties analyzed showed an error of less than $20 \%$ for a group of 20 subsamples, except for $\mathrm{P}$ and $\mathrm{K}$, which were capable of showing an error greater than $40 \%$ around the mean. The extreme variability in phosphorus, particularly at the depth of 0.2-0.4 m, attributed to banded application of high rates of $P$ fertilizers at planting, places limitations on assessment of its availability due to the high number of subsamples required for a composite sample.
\end{abstract}

Index terms: Saccharum spp., soil sampling, soil analysis, spatial distribution.

\footnotetext{
(1) Part of Master dissertation presented for the first author to Pos-graduation program in Agronomy at University of Brasília, Faculty of Agronomy and Veterinary Medicine, UnB-FAV. Received for publication on April 23, 2013 and approved on December 3, 2013.

(2) Master in Agronomy, University of Brasília, Faculty of Agronomy and Veterinary Medicine - UnB-FAV. Campus Universitário Darcy Ribeiro. CEP 70910-900 Brasília-DF. E-mail: j.avelino86@hotmail.com

(3) Associate Professor, UnB-FAV. E-mail: marilusa@unb.br

(4) Researcher, Embrapa Cerrados. BR 020, km 18. Caixa Postal 08223. CEP 73310-970, Brasília (DF). E-mail: thomaz.rein@embrapa.br, joao.jr@embrapa.br

(5) Adjunct Professor, UnB-FAV. E-mail: cicerocf@unb.br
} 


\title{
RESUMO: VARIABILIDADE DE ATRIBUTOS DE FERTILIDADE DO SOLO EM ÁREAS CULTIVADAS COM CANA-DE-AÇÚCAR NO ESTADO DE GOIÁS
}

\begin{abstract}
A amostragem de solo deve representar adequadamente a área avaliada, visando à elaboração de recomendações de medidas de correção da fertilidade e conservação dos solos, a fim de elevar a produtividade e melhorar o aproveitamento de insumos. O objetivo deste trabalho foi avaliar a variabilidade de atributos de fertilidade de Latossolos em áreas de renovação de cana-de-açúcar no Estado de Goiás. Foram selecionadas duas áreas de aproximadamente $8.100 \mathrm{~m}^{2}$ na usina Goiasa, municipio de Goiatuba, consideradas representativas de dois talhões cultivados com cana-de-açúcar, com espaçamento entrelinhas de 1,5 m. Em cada uma das áreas selecionadas, foi realizada amostragem do solo em malha, nas linhas de plantio e nas entrelinhas, com trado holandês. Coletaram-se amostras simples (subamostras) em 49 pontos amostrais nas linhas e 49 nas entrelinhas, nas profundidades de 0,0-0,2 e 0,2-0,4 m, totalizando 196 amostras simples em cada área de estudo, que foram analisadas individualmente. As amostras foram submetidas a análises químicas de fertilidade do solo ( $\mathrm{pH}$ em $\mathrm{CaCl}_{2}$, acidez potencial, matéria orgânica, $\mathrm{Pe} \mathrm{K}$, Ca e Mg) e análise granulométrica. Por meio dos dados, foi calculado o número de subamostras requeridas para a estimativa da média de cada atributo, a partir do coeficiente de variação e do erro percentual admitido em torno da média, para probabilidade de $95 \%$. Os atributos estudados apresentaram variabilidades diferenciadas nas áreas estudadas: alta (P e K); média (acidez potencial, Ca e Mg); e baixa (pH, matéria orgânica e argila). A extrema variabilidade nos teores de $P$, particularmente na profundidade de 0,2-0,4 m, atribuída à aplicação localizada de doses elevadas de fertilizantes fosfatados no plantio, impõe limitações à avaliação de sua disponibilidade pelo elevado número de subamostras requeridas para composição de uma amostra composta.
\end{abstract}

Termos de indexação: Saccharum spp., amostragem de solo, análises de solo, distribuição espacial.

\section{INTRODUCTION}

In the natural landscape, spatial and temporal variability of soil properties may occur due to several factors, including those responsible for soil formation (Montezano et al., 2006). Increased heterogeneity of soil properties is also continual and proportional to agricultural practices over time, including deforestation, soil tillage, crop rotation and fertilizer application method (banded or in the rows) (Cavalcante et al., 2007). These factors should therefore be considered in the sampling system for assessment of soil fertility.

With the increase in the sugarcane growing area (Saccharum officinarum) and its importance in Brazilian agribusiness, there has been a greater demand for techniques that provide an advanced growing system based on knowledge of spatial variability of soil properties, aimed at improving soil sampling for better use of resources and reduced cost (Campos et al., 2009).

One of the main difficulties encountered in representation of spatial variability of soil fertility properties in areas planted to sugarcane is determination of the number of subsamples required as a result of some soil amendment and fertilization techniques. Thus, the study of the distribution and composition of soil sampling has been a growing concern, so as to support procedures for use and recommendation of these techniques in different environments (Corá et al., 2004; Montanari et al., 2005; Souza et al., 2007).

With the intention of defining criteria for soil sampling under different farming systems in order to accurately estimate the mean values of determined properties, studies have adopted a procedure that consists of randomly collecting or systematically collecting (mesh, zig-zag) a given number of subsamples, analyzing them individually and calculating the coefficients of variation. It is necessary to establish the acceptable percentage of difference from the mean, obtain the values of the distribution table corresponding to the number of degrees of freedom and residue, and, thus, calculate the minimum number of subsamples for composition of the composite sample (Snedecor \& Cochran, 1967; Silveira et al., 2000; Alvarez V. \& Guarçoni, 2003). However, in sugarcane crops, previous sampling studies showed that in the estimate of soil fertility properties by the usual procedure, which recommends around 20 subsamples to form a composite sample, the average values of clay content, organic matter, and $\mathrm{pH}$ are estimated with an error of less than $10 \%$; values of $\mathrm{H}+\mathrm{Al}$ with an error of less than $15 \%$, and values of $\mathrm{P}, \mathrm{K}, \mathrm{Ca}$ and $\mathrm{Mg}$ with variation greater than $25 \%$ (Souza et al., 2006). The wide row spacing in sugarcane plantations (around $1.5 \mathrm{~m}$ ) and the localized application of fertilizers in the plant rows contribute to variability in soil sampling, as has been observed for farming systems of annual crops under 
no-tillage, for which there is no homogenization of the topsoil layer through annual preparation of the soil (Anghinoni, 2007).

Therefore, the present study aimed to assess the variability of fertility and clay content properties of Oxisols planted to sugarcane in two areas of the state of Goias, Brazil.

\section{MATERIALS AND METHODS}

The two study areas planted to sugarcane are in fields of the Goiasa sugarcane mill in the municipality Goiatuba, GO. The average altitude is $722 \mathrm{~m}$. The climate is characterized as semi-humid, with dry winters and rainy summers (Cwa in the Köppen climate classification).

Sampling Area 1 is located between the geographic coordinates $18^{\circ} 02^{\prime} 16^{\prime \prime}$ and $18^{\circ} 02^{\prime} 18^{\prime \prime}$ S and $49^{\circ} 44^{\prime} 36^{\prime \prime}$ and $49^{\circ} 44^{\prime} 32^{\prime \prime} \mathrm{W}$ (approximately $90 \mathrm{~m}$ width and length), with lightly rolling relief. The soil was classified according to Embrapa (2006) as a Latossolo Vermelho-Amarelo ácrico típico (LVAw) [Oxisol] with a clayey texture. The cultivated area was in the third sugarcane cycle and the sugarcane was mechanically harvested at the end of the season. Before sowing, split application of lime was carried out: $2.5 \mathrm{t} \mathrm{ha}^{-1}$ in October 2006 and $1.1 \mathrm{t} \mathrm{ha}^{-1}$ in April 2007. Sugarcane (SP 832847 variety) was mechanically planted in the furrow in April 2007 together with $600 \mathrm{~kg} \mathrm{ha}^{-1}$ of the fertilizer 02-25-20 (12 kg ha ${ }^{-1} \mathrm{~N}, 150 \mathrm{~kg} \mathrm{ha}^{-1} \mathrm{P}_{2} \mathrm{O}_{5}$ and $120 \mathrm{~kg} \mathrm{ha}^{-1} \mathrm{~K}_{2} \mathrm{O}$ ) in the furrow. Two fertirrigations were made (in April and May) to revitalize the soil. The first fertilizer application on the ratoon crop was performed in January 2009 using $450 \mathrm{~kg} \mathrm{ha}^{-1}$ of the fertilizer 20-0-20 incorporated in the soil between rows, close to the plant row. The second fertilizer application was performed in November 2009 using $17.9 \mathrm{t} \mathrm{ha}^{-1}$ of an organic compound produced with filter cake and boiler ash (waste from the sugarcane industry) with application between rows.

Sampling Area 2 is located between the geographical coordinates $18^{\circ} 01^{\prime} 11^{\prime \prime}$ and $18^{\circ} 01^{\prime} 11^{\prime \prime} \mathrm{S}$ and $49^{\circ} 38^{\prime} 51^{\prime \prime}$ and $49^{\circ} 38^{\prime} 55^{\prime \prime} \mathrm{W}$ (approximately 90 $\mathrm{m}$ width and length) with lightly rolling relief. The soil of the area was classified according to Embrapa (2006) as a Latossolo Vermelho ácrico típico (LVw) [Oxisol] with a very clayey texture. The area was in the second cycle of sugarcane. In the current cycle, $3.9 \mathrm{tha}^{-1}$ of limestone was applied before planting in September 2007. The sugarcane (RB 855536 variety) was planted in April 2008, with the application of $185 \mathrm{~kg} \mathrm{ha}^{-1}$ of MAP - monoammonium phosphate $\left(100 \mathrm{~kg} \mathrm{ha}^{-1}\right.$ of $\left.\mathrm{P}_{2} \mathrm{O}_{5}\right)$ in the planting furrow. This fertilization of the plant-cane was supplemented in August with $340 \mathrm{~kg} \mathrm{ha}^{-1}$ of the fertilizer 3-17-35, incorporated between rows and close to the plant rows during leveling tillage of the area. Fertilizer application on the ratoon crop was performed in January 2010 with $21.6 \mathrm{t} \mathrm{ha}^{-1}$ of the organic compound (filter cake and boiler ash) applied between the rows, and in February 2011 with $435 \mathrm{~kg} \mathrm{ha}^{-1}$ of the fertilizer 23-0-18, incorporated through tillage. Both areas were mechanically harvested without burning.

Soil sampling was performed in November 2011, a few weeks after harvest with the sugarcane already resprouted, using a Dutch auger at the depths of 0.0-0.2 and 0.2-0.4 m. Systematic sampling was used in both areas, with a sampling grid of approximately $15 \times 15 \mathrm{~m}$, consisting of 10 rows of sugarcane between-row spacing of $1.5 \mathrm{~m}$. The sampling was undertaken at 49 points along the crop rows according to best judgment in regard to their center, and at 49 points between rows, alternating distances of 0.25 , 0.50 and $0.75 \mathrm{~m}$ perpendicular to the row at the points sampled in the row. At each sampling point, samples were collected from the 0.0-0.2 and 0.2-0.4 layers, for a total of 196 subsamples in each area. The subsamples collected were air-dried, clods were broken up, and the material was passed through a sieve with $2 \mathrm{~mm}$ mesh to obtain fine air-dried soil fractions (TFSA), which were individually analyzed.

The following parameters were analyzed: $\mathrm{pH}$ in $0.01 \mathrm{~mol} \mathrm{~L}^{-1} \mathrm{CaCl}_{2}$; potential acidity $(\mathrm{H}+\mathrm{Al})$ extractable with $0.5 \mathrm{~mol} \mathrm{~L}^{-1}$ calcium acetate at $\mathrm{pH} 7.0$ determined by titration with $0.05 \mathrm{~mol} \mathrm{~L}^{-1} \mathrm{NaOH}$; organic matter by Walkley-Black method (Walkley \& Black, 1934); exchangeable $\mathrm{Ca}, \mathrm{Mg}$ and $\mathrm{Al}$ extracted with $1 \mathrm{~mol} \mathrm{~L}^{-1}$ potassium chloride, with $\mathrm{Ca}$ and $\mathrm{Mg}$ determined by atomic absorption spectroscopy and $\mathrm{Al}$ determined by titration with $0.05 \mathrm{~mol} \mathrm{~L}^{-1} \mathrm{NaOH} ; \mathrm{P}$ and $\mathrm{K}$ extracted by Mehlich-1 $\left(0.0125 \mathrm{~mol} \mathrm{~L}^{-1} \mathrm{H}_{2} \mathrm{SO}_{4}+0.05\right.$ mol L ${ }^{-1} \mathrm{HCl}$ ), with $\mathrm{P}$ determined by UV/Visible spectrophotometry and $\mathrm{K}$ by flame photometry. Particle size analysis was made by the pipette method after soil dispersion by $0.01 \mathrm{~mol} \mathrm{~L}^{-1} \mathrm{NaOH}$, with the addition of coarse sand to improve dispersion. Analyses were conducted by the methods described in Embrapa (1997), except for potential acidity (Raij et al., 2001).

Descriptive statistics of the analytical results of soil fertility properties of the subsamples in each area were generated with the aid of the statistical package of the Excel ${ }^{\circledR}$ program for obtaining the minimum values, maximum values, mean, standard deviation, coefficient of variation, asymmetry, kurtosis and Shapiro-Wilk's W test. We estimated the minimum number of subsamples to form a composite sample according to equation 1, used by Silveira et al. (2000), Carvalho et al. (2002), Alvarez V. \& Guarçoni (2003), Oliveira et al. (2007) and Rozane et al. (2011). The number of subsamples $(\mathrm{N})$ required for the estimate of the mean value of each property was calculated based on the coefficient of variation $(C V)$, the acceptable range of error from the mean $(f)$ and the $95 \%$ probability value $(t)$ : 


$$
N=\left(\frac{C V * t}{f}\right)^{2}
$$

The variability of the areas expressed through the parameters of descriptive statistics and the estimated number of subsamples required was assessed for each depth and sampling position (in the row and between rows), regardless of the position between rows with respect to the samples collected at $0.25,0.50$ and 0.75 $\mathrm{m}$ distances from the plant row.

\section{RESULTS AND DISCUSSION}

Tables 1 and 2 show the mean values and other statistical indicators of soil fertility properties of the two areas planted to sugarcane from the 49 respective subsamples (for the positions in the row and between rows) and sampling depths (0.0-0.2 and 0.2-0.4 m).

In respect to sampling depth, an increase in clay contents and a decrease in soil organic matter is observed in the two areas with increasing depth, which is characteristic of Oxisols. Decrease in organic matter content with greater depth in the 0.0-0.4 m layer is often observed in areas planted to sugarcane (Razafimbelo et al., 2006; Marques Júnior et al., 2008). Regarding sampling position, clay contents were almost the same in the row and between rows for each area and depth, with clay content being a property associated with soil genesis, little influenced by its management (Corá et al., 2004). Soil organic matter, in turn, showed a tendency to higher values in the row for both areas and depths, although the differences are not significant and may be attributed to the greater presence of roots in this position (Razafimbelo et al., 2006).

The main properties related to soil acidity $(\mathrm{pH}$ in $\mathrm{CaCl}_{2}, \mathrm{H}+\mathrm{Al}$, Ca and $\mathrm{Mg}$ ) were also found to be stratified, with higher $\mathrm{pH}$ values and $\mathrm{Ca}$ and $\mathrm{Mg}$ contents in the 0.0-0.2 m layer, reflecting the depth of the operations of soil tillage and incorporation of limestone. The same tendency was observed in another study in an Oxisol planted to sugarcane (Correia \& Alleoni, 2011). As for potential acidity ( $\mathrm{H}+\mathrm{Al})$, it was a little lower in the 0.0-0.2 $\mathrm{m}$ depth compared to the subsurface layer in Sampling Area 1, and the opposite occurred in Sampling Area 2. The differences in the effects of depth on potential acidity are related to liming levels (higher $\mathrm{pH}$ in Area 1) and organic matter content, the main source of $\mathrm{H}+\mathrm{Al}$ and, consequently, buffering of soil acidity (higher in Area 2). As observed for clay and organic matter, the properties related to soil acidity were little influenced by sampling position, through comparison of in the row and between rows at each depth. This fact reflects broadcast liming with incorporation in the total area, with limestone being the main corrective agent of acidity and source of $\mathrm{Ca}$ and Mg.
Unlike the other properties, the sampling position and depth were found to affect the levels of $\mathrm{P}$ and $\mathrm{K}$. The higher levels of $\mathrm{K}$ at the 0.0-0.2 $\mathrm{m}$ depth observed in both areas reflect annual application of mineral fertilizer (formulations with potassium chloride) and fertilization with an organic compound produced from waste from the mill (filter cake and boiler ash) on the ratoon crop, as well as $\mathrm{K}$ recycling through quick washing away of $\mathrm{K}$ from crop litter from mechanized harvest (Oliveira et al., 2007). In the 0.0-0.2 m layer, the $\mathrm{K}$ contents in the row were higher, approximately twice as high compared to the contents between rows, in both areas, with the smallest differences observed in the 0.2-0.4 $\mathrm{m}$ layer. The annual application of fertilizer on the ratoon crop close to the crop row and recycling of K from plants to the soil, through washing of leaves and other senescent tissues by rain water close to the crop row, may also explain the higher content in the row compared to the content between rows. This type of recycling was observed in the corn crop (Silva \& Ritchey, 1982) in which, after broadcast application of $\mathrm{K}$ at planting, a higher level was observed on the surface in the crop row at the end of the cycle.

The two areas showed different tendencies regarding the effects of position and depth on $\mathrm{P}$ levels. In Area 1, the highest level was observed in the 0.2-0.4 m layer in the row, $5.4 \mathrm{mg} \mathrm{dm}^{-3}$, an availability classified as average for clay soil (Sousa et al., 2002). At the same position in the 0.0-0.2 m layer, the average content was $1.4 \mathrm{mg} \mathrm{dm}^{-3}$. This effect of depth can be explained by the application of high rates of phosphate fertilizer $\left(150 \mathrm{~kg} \mathrm{ha}^{-1}\right.$ of $\left.\mathrm{P}_{2} \mathrm{O}_{5}\right)$ in the furrow at the time of sugarcane planting, usually below the depth of $0.3 \mathrm{~m}$. The low mobility of $\mathrm{P}$ in the soil and the slow uptake by the crop cause a long residual effect in this layer, which was detected by soil analysis. Between rows, $\mathrm{P}$ contents were approximately $2 \mathrm{mg} \mathrm{dm}^{-3}$ in both depths in Area 1 .

In Area 2, in the 0.0-0.2 m layer, $\mathrm{P}$ contents were similar for in the row and between row positions, close to $6 \mathrm{mg} \mathrm{dm}^{-3}$, an availability classified as suitable for a soil with high clay content (Sousa et al., 2002). As for the 0.2-0.4 $\mathrm{m}$ layer, $\mathrm{P}$ content was higher in the row $\left(5.9 \mathrm{mg} \mathrm{dm}^{-3}\right)$ compared to between rows $\left(2.3 \mathrm{mg} \mathrm{dm}^{-3}\right)$. In this Area, there was split application of phosphate fertilizer at planting: approximately $100 \mathrm{~kg} \mathrm{ha}^{-1}$ of $\mathrm{P}_{2} \mathrm{O}_{5}$ applied in the furrow and $60 \mathrm{~kg} \mathrm{ha}^{-1}$ applied close to the plant row and incorporated in the soil surface during leveling tillage between rows. This split application of phosphate fertilizer for plant-cane, as well as fertilization of ratoon-cane with $21.6 \mathrm{tha}^{-1}$ of organic compound carried out in the year prior to sampling, may explain the higher $\mathrm{P}$ contents in the 0.0-0.2 m layer. Since the organic compound may have a content higher than $0.5 \%$ of $\mathrm{P}_{2} \mathrm{O}_{5}$ in its moist composition (Rossetto et al., 2010), this application corresponds to approximately $110 \mathrm{~kg} \mathrm{ha}^{-1}$ of $\mathrm{P}_{2} \mathrm{O}_{5}$. There are no known records of the two areas regarding annual crops and fertilizations carried out in renewal 


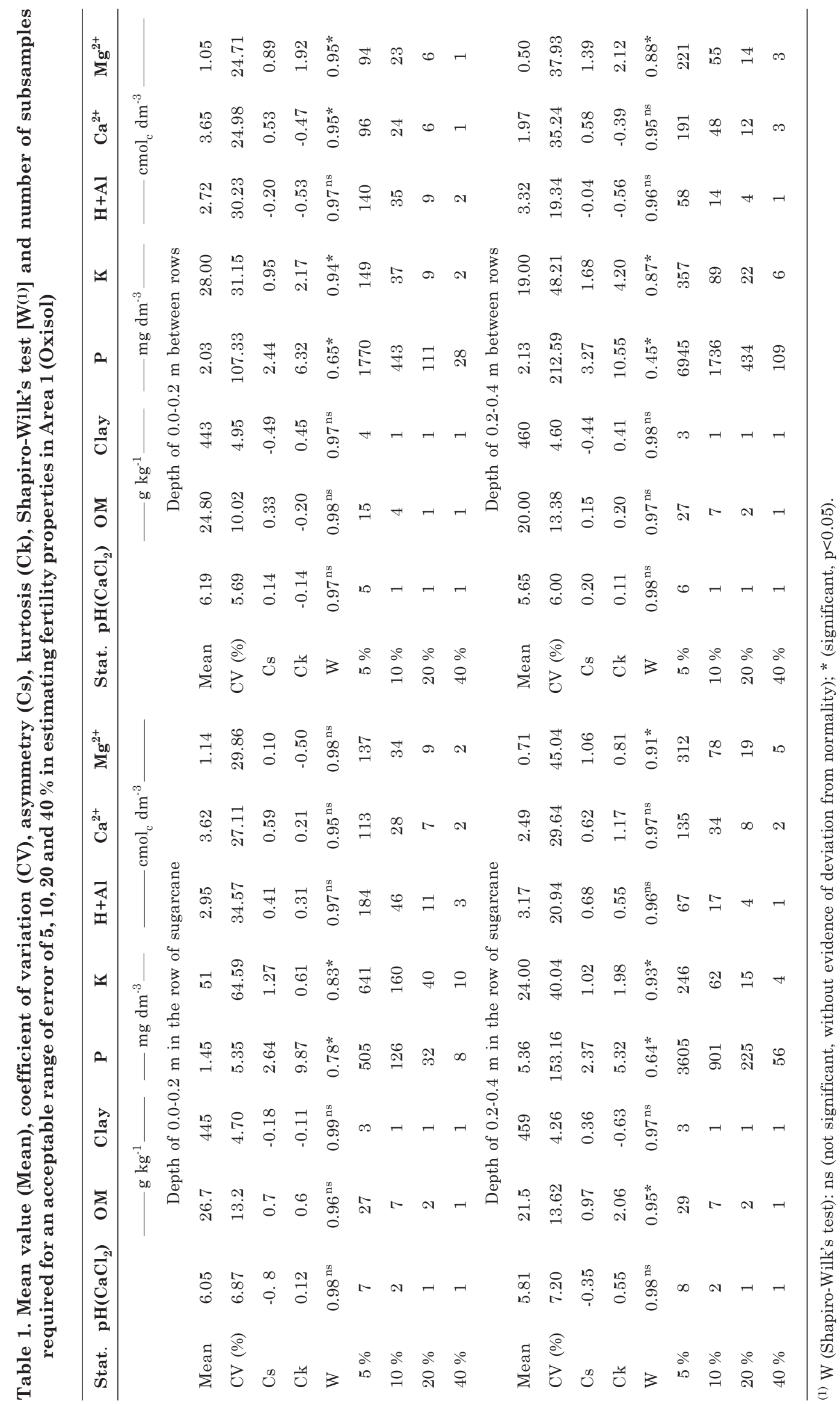




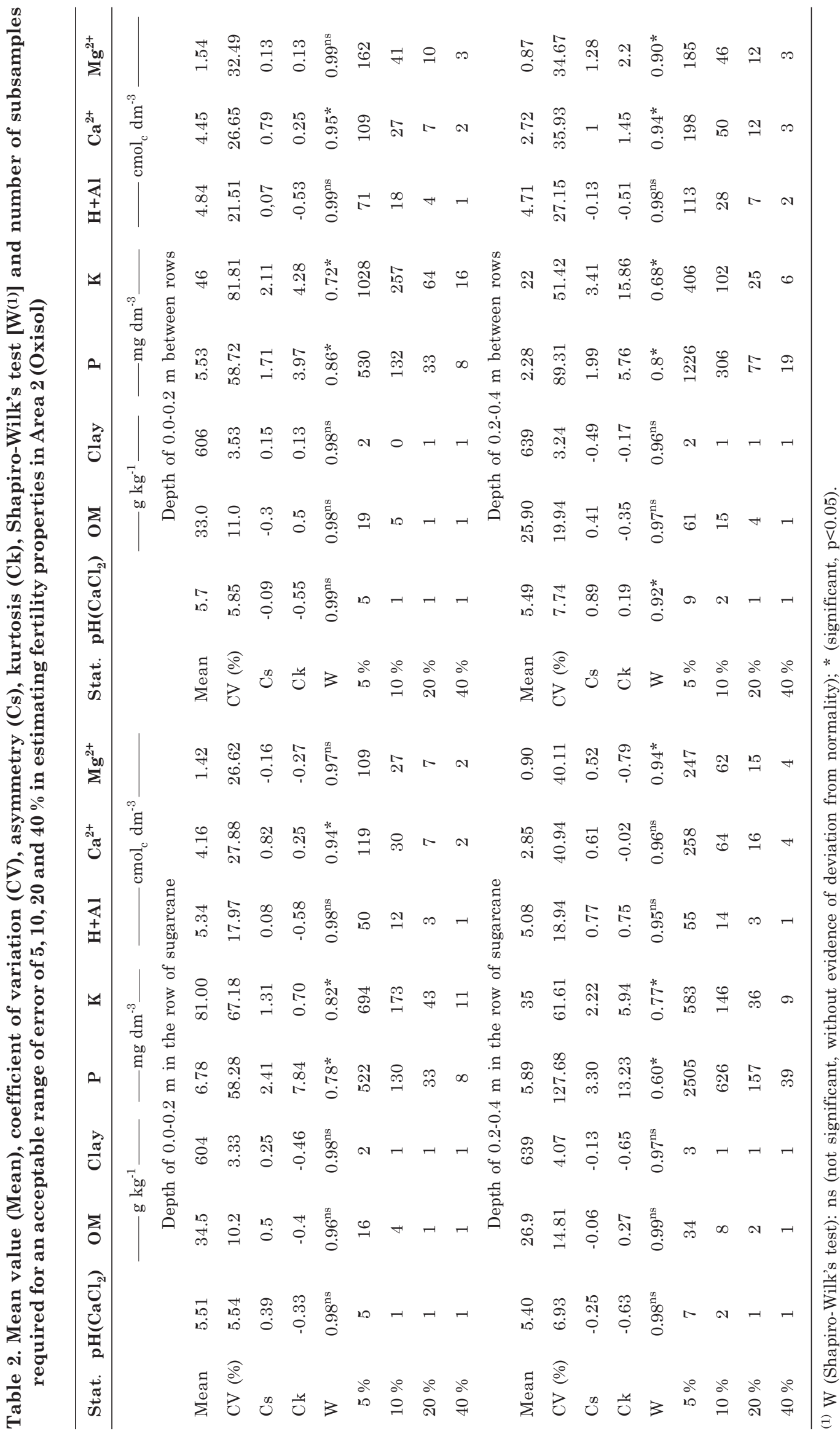


of the sugarcane crop. Areas 1 and 2 underwent one and two previous cycles of sugarcane growing, respectively, with fertilization in the plant furrow.

The above comparisons of average values reveal vertical stratification (depth) and horizontal stratification (in the row and between rows) of soil fertility properties, explained by the nature of the property and soil and crop management. Vertical stratification was observed for all the properties. As for horizontal stratification, it was mainly observed for $\mathrm{P}$ and $\mathrm{K}$. We now direct our attention to soil variability in the sampling, referred to here as the variability of the results from subsamples in each sampling position and depth, expressed through the coefficient of variation (CV) and the estimated number of subsamples required for a composite sample with an acceptable range of error of 5, 10, 20 and $40 \%$ (Tables 1 and 2).

The distributions of the results of the subsamples for each property are shown in tables 1 and 2 by asymmetry (Cs), kurtosis (Ck) and Shapiro-Wilk's W test. Similar trends were observed in the two areas. Marked deviations from normal distribution were detected for $\mathrm{K}$ and particularly for $\mathrm{P}$, which showed the highest (positive) values for kurtosis and asymmetry, associated with a wide range and very high levels of $\mathrm{P}$ in few samples (data not shown), conferring log-normal distribution to the data. Significant deviations from normality for P and K were also observed by Barbieri et al. (2008), Campos et al. (2008) and Oliveira Junior et al. (2010).

Warrick \& Nielsen (1980) classified the coefficients of variation (CV) for soil properties as low ( $\leq 12 \%)$, medium $(12 \%<\mathrm{CV}<24 \%)$, and high $(\geq 24 \%)$. According to this criterion, $\mathrm{pH}$ in $0.01 \mathrm{~mol} \mathrm{~L}^{-1} \mathrm{CaCl}_{2}$ and clay content showed lower $\mathrm{CV}$ values in both sampling positions and depths in the two areas (Tables 1 and 2). The $\mathrm{CVs}$ for $\mathrm{pH}$ and clay content were always below 8 and $5 \%$, respectively. This reflects the genetic nature of clay content, which is little influenced by soil management, and the small size of the study areas (less than $1 \mathrm{ha}$ ) since significant horizontal texture gradients can be found in crop fields. In regard to $\mathrm{pH}$ variability, mainly determined by the degree of uniformity in broadcast application and incorporation of limestone, the low CV partly reflects the logarithmic nature of this property. Low coefficients of variation for $\mathrm{pH}$ and clay content have been reported in areas planted to sugarcane and other crops (Silveira et al., 2000; Carvalho et al., 2002; Corá et al., 2004; Montanari et al., 2005; Montezano et al., 2006; Oliveira et al., 2007; Rozane et al., 2011).

The CVs for organic matter are classified as low and medium, close to the limit of $12 \%$ (ranging from 10.0 to $14.8 \%$ ) in most cases, except for between rows at the depth of 0.20-0.40 m in Area 2 (19.9\%). Similar types of variation for organic matter in soils planted to sugarcane were reported by Corá et al. (2004) and Marques Júnior et al. (2008).
Regarding the other properties associated with soil acidity ( $\mathrm{Ca}, \mathrm{Mg}$ and $\mathrm{H}+\mathrm{Al})$, the $\mathrm{CVs}$ were classified as medium $(12 \%<\mathrm{CV}<24 \%)$ to high $(\geq 24 \%)$. As for potential acidity, CV values ranged from 18.0 to $34.6 \%$, without consistent trends regarding areas, horizontal positions and depths. Regarding $\mathrm{Ca}$ and $\mathrm{Mg}, \mathrm{CVs}$ values ranged from 25.0 to $40.9 \%$ and from 24.7 to $45.0 \%$, respectively. Unlike $\mathrm{H}+\mathrm{Al}$, higher CV values were observed for $\mathrm{Ca}$ and $\mathrm{Mg}$ at the depth of 0.2-0.4 m than at the depth of 0.0-0.2 m, in the row and between rows, for both areas. High coefficients of variation for $\mathrm{Ca}$ and $\mathrm{Mg}$ in soils planted to sugarcane are reported in the literature (Corá et al., 2004; Montanari et al, 2005; Souza et al., 2007).

The properties $\mathrm{K}$ and, especially, $\mathrm{P}$, showed high variability $(\mathrm{CV} \geq 24 \%)$ in all situations. The $\mathrm{CV}$ for $\mathrm{K}$ ranged from 31.1 to $81.8 \%$, with lower values in Area 1 than Area 2, without consistent tendencies regarding positions in the row and between rows and sampling depths. CV values for P ranged from 57.3 to $212.6 \%$, with the greatest variability occurring at the depth of 0.2-0.4 $\mathrm{m}$ for the positions in the row and between rows, in the two areas. According to Vanni (1998), a CV between 35 and $65 \%$ indicates that the series is homogeneous and the average is not significant but can still be representative of the series. This is the case of $\mathrm{K}$, for most situations in tables 1 and 2 . Conversely, when the CV is higher than $65 \%$, the series is considered very heterogeneous, and the average is not significant. That is the case of $\mathrm{P}$, for most situations. High variability for $\mathrm{P}$ and $\mathrm{K}$ was reported in soils planted to sugarcane (Corá et al., 2004; Montanari et al., 2005; Souza et al., 2007), generally a little higher than for the other properties assessed in these studies.

The higher coefficients of variation for $\mathrm{K}$ and, especially, $\mathrm{P}$ regarding the soil acidity properties reflect the mode of localized application of fertilizers in the furrows, or in narrow bands next to the rows of sugarcane, whereas the agents for amendment of acidity are broadcast and incorporated in the entire area. Regarding $\mathrm{P}$, the greater variability found in the 0.2-0.4 m layer compared to the 0.0-0.2 m layer in the row and between rows can be explained by the long residual effect of $\mathrm{P}$ applied at the bottom of the furrows (usually below $0.3 \mathrm{~m}$ ), in the present cycle of sugarcane and in previous cycles, since the soil in general is not worked with a harrow disc at this depth during soil tillage activities. Since the band for application of fertilizers in the furrows is narrow, the doses of $\mathrm{P}$ are high, and the spacing between rows of sugarcane is wide $(1.5 \mathrm{~m})$, the separation and concentration of $\mathrm{P}$ in the furrows are high. The possible variability in mechanized distribution of fertilizers along the planting furrow and the low mobility and redistribution of $\mathrm{P}$ in the soil, associated with point sampling with the Dutch auger at depths of 0.0-0.2 and 0.2-0.4 m may partially explain the high variability observed for $P$. Uncertainty regarding the 
central position of the planting furrow and, consequently, the location of the fertilizer applied, surely contributes to the variability observed. Thus, through best judgment regarding the center of the furrow in sampling, the fertilized zone at the bottom of the furrow is not sampled in some measurements with the Dutch auger. Unlike K, recycling and redistribution of $\mathrm{P}$ in the total area of the surface layer through crop litter from mechanized harvest are low, for the amounts taken up by the crop are significantly lower compared to K (Rosseto et al., 2010).

Based on the coefficients of variation, we calculated the number of subsamples required for formation of the composite sample for estimating the mean values of the properties in each position and depth of sampling in the two areas (Tables 1 and 2). The number of subsamples required was estimated for different acceptable ranges of error $(5,10,20$ and $40 \%)$ and a level of significance of $95 \%$. These numbers are directly related to the coefficient of variation and inversely related to the acceptable error, ranging from 1 to 6,945 subsamples. For assessment of soil fertility, Raij (1991) suggests the values of $5 \%$ for $\mathrm{pH}, 10 \%$ for clay content and $20 \%$ for organic matter, $\mathrm{Ca}, \mathrm{Mg}$ and $\mathrm{K}$ as acceptable ranges of error from the mean. In this study, a $20 \%$ error was accepted for P.

Regarding the properties that showed the lowest coefficients of variation, the number of subsamples required for $\mathrm{pH}$ in $0.01 \mathrm{~mol} \mathrm{~L}^{-1} \mathrm{CaCl}_{2}$ (acceptable error of $5 \%$ ) ranged from 5 to 9 ; for clay content (acceptable error of $10 \%$ ), it was only 1 in all the situations assessed; and for organic matter (acceptable error of $20 \%$ ), it ranged from 1 to 4 . For other properties related to soil acidity (acceptable error of $20 \%$ ), the number of subsamples required ranged from 6 to 16 for Ca; from 6 to 9 for $\mathrm{Mg}$; and from 3 to 11 for $\mathrm{H}+\mathrm{Al}$.

For $\mathrm{P}$ and $\mathrm{K}$, which showed the highest coefficients of variation, the number of subsamples required was significantly higher than for the other properties. With an acceptable error of $20 \%$, from 9 to 64 subsamples are required for K. Only in two situations, in Area 1 (in the row at 0.2-0.4 m; between rows at 0.2-0.4 m), less than 20 subsamples were required for K. Regarding P, in Area 1, from 32 to 434 subsamples were required for the same acceptable error. The numbers of subsamples required were also greater at the depth of 0.2-0.4 m, which can be explained by the long residual effect of phosphate fertilizers at the bottom of the furrow, applied in the current and previous cycles of sugarcane, as already discussed. In this layer, the number of subsamples required ranged from 77 to 434 .

In soil sampling for crops in general, and for sugarcane growing in particular, it is usually recommended to take 20 subsamples at random for a composite sample in fertility assessment of the topsoil layer (0.0-0.2 or 0.0$0.25 \mathrm{~m})$, regardless of the position, in the row or between rows (Rossetto et al., 2008). There is also the recommendation of taking 15 subsamples from between rows only within a few inches of the row (Vitti et al., 2010). Based on the criterion of 20 subsamples, considering in the row and between row positions separately in this study, except for $\mathrm{P}$ and $\mathrm{K}$, the properties would be estimated with errors within the acceptable range. As the mean values and coefficients of variation related to these properties were little influence by in the row and between row positions at each depth, random sampling of the areas considering 20 subsamples would allow an adequate assessment of soil fertility for these properties at each depth.

In contrast, the criterion of 20 subsamples would lead to errors beyond the acceptable range in assessment of soil fertility for K, particularly at the depth of 0.0-0.2 $\mathrm{m}$ where the levels and coefficients of variation were higher. In the case of $\mathrm{P}$, in all the situations assessed, its availability would be estimated with errors beyond the acceptable range, particularly at the depth of 0.2-0.4 m. Since the averages and coefficients of variation related to $\mathrm{P}$ and $\mathrm{K}$ were influenced by in the row and between row positions, random sampling of the areas without regard for the position, as is usually done, may lead to errors even greater than those observed, when estimating the average levels of these nutrients, and a greater number of subsamples would be required. This is also the case in recommendations based on the composition of the sample as of a given number of subsamples taken in the rows and between rows (Chitolina et al., 2009), so as to obtain a more representative sample.

The findings of this study indicate localized fertilizer applications as the main source of variability in soil sampling in sugarcane crops. This situation is similar to that found in areas growing annual species under no-tillage with fertilization in the furrows, which require a greater number of subsamples compared to areas where the soil is tilled for planting every crop season, with a more homogeneous topsoil layer (Carvalho et al., 2002; Anghinoni, 2007). Strategies that consider soil analyses associated with fertilization history are necessary for adequate fertility assessment of areas planted to sugarcane.

\section{CONCLUSIONS}

1. The properties assessed showed different types of variation in the areas under study: high ( $\mathrm{P}$ and $\mathrm{K})$; medium (potential acidity; $\mathrm{Ca}$ and $\mathrm{Mg}$ ) and low $(\mathrm{pH}$, organic matter and clay), requiring different numbers of subsamples for suitable chemical characterization of the areas planted to sugarcane.

2 . The extreme variability in phosphorus contents, particularly at the 0.2-0.4 $\mathrm{m}$ depth, due to localized application of high rates of phosphate fertilizer at planting, imposes limitations on assessment of its availability because of the large number of subsamples required to form a composite sample. 


\section{ACKNOWLEDGMENTS}

To CAPES, for granting a Master's degree scholarship to the first author, to the Goiasa sugarcane mill for providing the physical space needed and for collaboration in soil sampling, and to Embrapa Cerrados for support in developing our study.

\section{LITERATURE CITED}

ANGHINONI, I. Fertilidade do solo e seu manejo no sistema plantio direto. In: NOVAIS, R.F.; ALVAREZ V., V.H.; BARROS, N.F.; FONTES, R.L.F.; CANTARUTTI, R.B. \& NEVES, J.C.L., eds. Fertilidade do solo. Viçosa, MG, Sociedade Brasileira de Ciência do Solo, 2007. p.873-928.

ALVAREZ V., V.H. \& GUARÇONI, M.A. Variabilidade horizontal da fertilidade do solo de uma unidade de amostragem em sistema plantio direto. R. Bras. Ci. Solo, 27:297-310, 2003.

BARBIERI, D.M.; MARQUES JÚNIOR, J. \& PEREIRA, G.T. Variabilidade espacial de atributos químicos de um Argissolo para a aplicação de insumos à taxa variável em diferentes formas de relevo. Eng. Agríc., 28:645-653, 2008.

CAMPOS, M.C.C.; MARQUES JÚNIOR, J.; PEREIRA, G.T.; SOUZA, Z.M. \& BARBIERI, D.M. Aplicação de adubo e corretivo após o corte da cana-planta utilizando técnicas geoestatísticas. Ci. Rural, 38:974-980, 2008.

CAMPOS, M.C.C.; MARQUES JÚNIOR, J.; PEREIRA, G.T.; SOUZA, Z.M. \& MONTANARI, R. Planejamento agrícola e implantação de sistema de cultivo de cana-de-açúcar com auxílio de técnicas geoestatísticas. R. Bras. Eng. Agríc. Amb., 13:297-304, 2009.

CARVALHO, J.R.P.; SILVEIRA, P.M. \& VIEIRA, S.R. Geoestatística na determinação da variabilidade espacial de características químicas do solo sob diferentes preparos. Pesq. Agropec. Bras., 37:1151-1159, 2002.

CAVALCANTE, E.G.S.; ALVES, M.C.; SOUZA, Z.M. \& PEREIRA, G.T. Variabilidade espacial de atributos químicos do solo sob diferentes usos e manejos. R. Bras. Ci. Solo, 31:1329-1339, 2007.

CHITOLINA, J.C.; PRATA, F.; SILVA, F.C.; COELHO, A.M.; CASARINI, D.C.P.; MURAOKA, T.; VITTI, A.C. \& BOARETTO, A.E. Manual de análises químicas de solos, plantas e fertilizantes. 2.ed. Brasília, Embrapa Informação Tecnológica, 2009. p.25-57.

CORÁ, J.E.; ARAÚJO, A.V.; PEREIRA, G.T. \& BERALDO, J.M.G. Variabilidade espacial de atributos do solo para adoção do sistema de agricultura de precisão na cultura de cana-de-açúcar. R. Bras. Ci. Solo, 28:1013-1021, 2004.

CORREIA, B.L. \& ALLEONI, L.R.F. Conteúdo de carbono e atributos químicos de Latossolo sob cana-de-açúcar colhida com e sem queima. Pesq. Agropec. Bras., 46:944-952, 2011.

EMPRESA BRASILEIRA DE PESQUISA AGROPECUÁRIA EMBRAPA. Centro Nacional de Pesquisa do Solo. Sistema brasileiro de classificação de solos. 2.ed. Rio de Janeiro, 2006. 306p.
EMPRESA BRASILEIRA DE PESQUISA AGROPECUÁRIA EMBRAPA. Centro Nacional de Pesquisa do Solo. Manual de métodos de análise do solo. 2.ed. Rio de Janeiro, 1997. 212p.

MARQUES JÚNIOR, J.; SOUZA, Z.M.; PEREIRA, G.T. \& BARBIERI, D.M. Variabilidade espacial de matéria orgânica, P, K e CTC de um Latossolo cultivado com cana-de-açúcar por longo período. R. Biol. Ci. Terra, 8:143-152, 2008.

MONTANARI, R.; MARQUES JÚNIOR, J.; PEREIRA, G.T. \& SOUZA, Z.M. Forma da paisagem como critério para otimização amostral de Latossolos sob cultivo de canade-açúcar. Pesq. Agropec. Bras., 40:69-77, 2005.

MONTEZANO, Z.F.; CORAZZA, E.J. \& MURAOKA, T. Variabilidade espacial da fertilidade do solo em área cultivada e manejada homogeneamente. R. Bras. Ci. Solo, 30:839-47, 2006

OLIVEIRA, F.H.T.; ARRUDA, J.A.; SILVA, I.F. \& ALVES, J.C. Amostragem para avaliação da fertilidade do solo em função do instrumento de coleta das amostras e de tipos de preparo do solo. R. Bras. Ci. Solo, 31:973-983, 2007.

OLIVEIRA JUNIOR, J.C.; SOUZA, L.C.P. \& MELO, V.F. Variabilidade de atributos físicos e químicos de solos da formação Guabirotuba em diferentes unidades de amostragem. R. Bras. Ci. Solo, 34:1491-1502, 2010.

RAIJ, B.van; ANDRADE, J.C.; CANTARELLA, H. \& QUAGGIO, J.A., eds. Análise química para avaliação da fertilidade de solos tropicais. Campinas, Instituto Agronômico de Campinas, 2001. 285p.

RAIJ, B.van. Fertilidade do solo e adubação. Piracicaba, Agronômica Ceres, 1991. 343p.

RAZAFIMBELO, T.; BARTHÈS, B.; LARRÉ LARROUY, M.C.; LUCA, E.F.; LAURENT, J.Y.; CERRI, C.C. \& FELLER, C. Effect of sugarcane residue management (mulching versus burning) on organic matter in a clayey Oxisol from southern Brazil. Agric. Ecosyst. Environ., 115:285-289, 2006.

ROSSETTO, R.; CANTARELLA, H.; DIAS, F.L.F.; VITTI, A.C. \& TAVARES, S. Cana-de-açúcar. In: PROCHONOW, L.I.; CASARIN, V. \& STIPP, S.R., eds. Boas práticas para o uso eficiente de fertilizantes. Piracicaba, INPI-Brasil, 2010. p.160-230.

ROSSETTO, R.; DIAS, F.L.F. \& VITTI, A.C. Fertilidade do solo, nutrição e adubação. In: DINARDO-MIRANDA, L.L.; VASCONCELOS, A.C.M. \& LANDELL, M.G.A., eds. Campinas, Instituto Agronômico, 2008. p.221-238.

ROZANE, D.E.; ROMUALDO, L.M.; CENTURION, J.F. \& BARBOSA, J.C. Dimensionamento do número de amostras para avaliação da fertilidade do solo. Semina: Ci. Agron., 32:111-118, 2011.

SILVA, J.E. \& RITCHEY, K.D. Acumulação diferencial de potássio em Oxissolos devido a lavagem do nutriente das plantas de milho para o solo. R. Bras. Ci. Solo, 6:183188, 1982. 
SILVEIRA, P.M.; ZIMMERMANN, F.J.P.; SILVA, S.C. \& CUNHA, A.A. Amostragem e variabilidade espacial de características químicas de um Latossolo submetido a diferentes sistemas de preparo. Pesq. Agropec. Bras., 35:2057-2064, 2000.

SOUSA, D.M.G.; LOBATO, E \& REIN, T.A. Adubação com fósforo. In: SOUSA, D.M.G. \& LOBATO, E., ed. Cerrado: Correção do solo e adubação. Planaltina, Embrapa Cerrados, 2002. p.147-168.

SOUZA, Z.M.; BARBIERI, D.M.; MARQUES JÚNIOR, J.; PEREIRA, G.T. \& CAMPOS, M.C.C. Influência da variabilidade espacial de atributos químicos de um Latossolo na aplicação de insumos para cultura da canade-açúcar. Ci. Agrotec., 31:371-377, 2007.

SOUZA, Z.M.; MARQUES JÚNIOR, J.; PEREIRA, G.T.; MONTANARI, R. \& CAMPOS, M.C.C. Amostragem de solo para determinação de atributos químicos e físicos em área com variação nas formas do relevo. Cientifíca, 34:249$256,2006$.
SNEDECOR, G.W. \& COCHRAN, W.G. Sampling from a normally distributed population. In: Statistical methods. 6.ed. Ames, Iowa State University Press, 1967. p.32-65.

VANNI, S.M. Modelos de regressão: Estatística aplicada. São Paulo, Legmar Informática \& Editora, 1998. 177p.

VITTI, G.C.; LUZ, P.H.C. \& ALTRAN, W.S. Nutrição e adubação. In: SANTOS, F.; BOREM, A. \& CALDAS, C., ed. Cana-de-açúcar: Bioenergia, açúcar e álcool tecnologia e perspectivas. Viçosa, MG, Universidade Federal de Viçosa, 2010. p.73-177.

WALKLEY, A. \& BLACK, I.A. An examination of the Degtjareff method for determining soil organic matter and a proposed modification of the chromic acid titration method. Soil Sci., 37:29-38, 1934.

WARRICK, A.W. \& NIELSEN, D.R. Spatial variability of soil physical properties in the field. In: HILLEL, D., ed. Applications of soil physics. New York, Academic Press, 1980. p.319-344. 